\title{
The Effect of Hydrogen Enrichment on The Exhaust Emission Characteristic in A Spark Ignition Engine Fueled by Gasoline-Bioethanol Blends
}

\author{
Abdul Rahman, Asnawi*, Reza Putra, Hagi Radian, Tri Waluyo \\ Department of Mechanical Engineering, Universitas Malikussaleh, Aceh, Indonesia \\ *Corresponding author E-mail: asnawi@unimal.ac.id
}

Manuscript received 30 Nov 2021; revised 3 Dec 2021; accepted 10 Jan 2022. Date of publication 10 April 2022

\begin{abstract}
Bioethanol characteristics can be used as an alternative fuel to spark-ignition (SI) engines to reduce emissions. This experiment evaluates the production of emissions for SI engines using hydrogen enrichment in the gasoline-bioethanol fuel blends. The fraction of bioethanol fuel blend was added to the gasoline fuel of $10 \%$ by volume and hydrogen fuel produced by the electrolysis process with a dry cell electrolyzer. The $\mathrm{NaOH}$ was used as an electrolyte which is dissolved in water of $5 \%$ by a mass fraction. The test is conducted using a singlecylinder $155 \mathrm{cc}$ gasoline engine with sensors and an interface connected to a computer to control loading and record all sensor variables in real-time. Hydrogen produced from the electrolysis reactor is injected through the intake manifold using two injectors, hydrogen injected simultaneously at a specific time with a gasoline-bioethanol fuel. The test was conducted with variations of engine speeds. The emission product of ethanol-- $\mathrm{H}_{2}\left(\mathrm{BE} 10+\mathrm{H}_{2}\right)$ was an excellent candidate as a new alternative of fuel solution in the future. The engasolinerichment of hydrogen increased the flame speed and generated a stable combustion reaction. The hydrogen enrichment produced $\mathrm{CO}_{2}$ emission due to the unavailability of carbon content in hydrogen fuel. As a result, the $\mathrm{C} / \mathrm{H}$ ratio is lower than for mixed fuels.
\end{abstract}

Keywords: Emission, Gasoline, Bioethanol, Hydrogen Enrichment.

\section{Introduction}

The energy consumption in the world is increasing every day, which affects increased emissions produced. Environment protection issues have become important worldwide to reduce emissions in the atmosphere. Biofuels have contributed to reducing $\mathrm{CO}_{2}, \mathrm{CO}$, and $\mathrm{NOx}$ in the atmosphere compared to fossil fuels. The continuous increase in consumption of fossil fuels directly contributes to being threatened by climate change. Energy consumption from the transportation sector has become a world problem. The world's energy demand is increasing every day, and the issue of fossil fuel depletion is becoming increasingly crucial, which has led to the development of alternative fuels for the future $[1,2]$. Currently, alternative energy sources such as bioethanol as an energy source in the transportation sector have become the focuses of researchers to develop and utilize bioethanol as fuel in spark-ignition engines with higher energy conversion and lower greenhouse gas emissions. Ethanol has been successfully introduced in fuel additives, blend fuels, and bi-fuels as an alternative fuel for sparkignition engines [3], according to recommendations issued by the Indonesian government regarding the selection of fuel types with low carbon content, efficient and environmentally friendly. Bioethanol is the alternative fuel for fuel diversification in an automotive vehicle [4]. The properties of gasoline bioethanol blends are suitable as an alternative fuel in spark-ignited engines. The higher oxygen content in bioethanol can increase combustion speed and internal efficiency [2, 5]. By using up to $15 \%$ of Using up to $15 \%$ of bioethanol in the gasoline, the blend has decreased spec fuel consumption by about $15.7 \% \mathrm{CO}$ emission [6]. The increase of thermal brake efficiency also resulted from experimental bioethanol fueled on SI engine with different excess air ratios for the engine load of 25\% and 50\% [7]. In the future, energy should be greener and more efficient. Hydrogen is the most effective alternative fuel for reducing or eliminating harmful vehicle emissions and their environmental impact compared to other alternative fuels. Hydrogen is widely available and one of the most valuable alternatives to fossil fuels today because it is one of the many elements found in the atmosphere. This study focused on the effect of hydrogen enrichment on the emission generated from the fuel mixture on the SI engine. Using hydrogen in combination with petroleumderived fuels in internal combustion engines can reduce harmful exhaust emissions from fossil fuels. One of the essential properties of hydrogen is hydrogen is the most effective to reduce or eliminate harmful vehicle emissions and their environmental impact. One of the essencrucial properties of hydrogen is the most effective to reduce or eliminate harmful vehicle emissions and their environmental impact $[8]$. 


\section{Literature Review}

Biofuels can be produced directly from plants or industrial, commercial, domestic, or agricultural waste. Biofuels offer the possibility of making energy without increasing the atmosphere's carbon content because the various plants used to produce biofuels reduce carbon dioxide levels, unlike fossil fuels, which return carbon stored beneath the soil surface for millions of years to the air. The development of biofuel energy conversion is defined into three generations, the first generation of raw materials from food crops such as corn, sugar cane, cassava, and others. The second generation of biofuels is made from non-food crops, namely lignocellulosic biomass derived from agricultural waste such as empty fruit bunches of oil palm, sugarcane bagasse, reeds, sweet potato pulp, and others. Third-generation biofuels derived explicitly from microalgae are considered technically feasible alternative energy sources that do not have ficant drawbacks associated with first- and second-generation biofuels [9]. Bioethanol $\left(\mathrm{C}_{2} \mathrm{H}_{5} \mathrm{OH}\right)$ is one of the most exciting biofuels present as an environmentally friendly and renewable alternative fuel [10]. The bioethanol characteristics are excellent for the SI engine; it has a higher Research Octane Number and flammability limit [1,11]. The properties of fuels are shown in Table 1. Hydrogen is the cleanest fuel, having a more extensive flammability range than gasoline fuel, and has a higher flame speed to produce peak pressure during the combustion process[12]. A small amount of hydrogen enrichment in the gasoline fuel-air mixture makes an explosive mixture, and the engine allows operating at the lean mix [13]. Hydrogen can reduce pollutant levels in the atmosphere. The global warming potential of hydrogen is not significant compared to hydrocarbon-based fuels because hydrogen combustion does not produce carbon-based compounds such as $\mathrm{HC}, \mathrm{CO}$, and $\mathrm{CO}_{2}$. Hydrogen is perfect to use as a fuel because it has the highest heating value among the existing powers in the form of a mass fraction, which is $119.93 \mathrm{MJ} / \mathrm{kg}$, and a flame velocity of $237 \mathrm{~cm} / \mathrm{s}$, with a RON of 130 [14]

Table 1. The physical and chemical properties of Gasoline, Bioethanol, and Hydrogen [6, 15-17]

\begin{tabular}{ccccc}
\hline Property & Units & Gasoline & Bioethanol & Hydrogen \\
\hline Chemical formula & - & $\mathrm{C}_{5}-\mathrm{C}_{12}$ & $\mathrm{C}_{2} \mathrm{H}_{5} \mathrm{OH}$ & $\mathrm{H}$ \\
\hline Composition $(\mathrm{C}, \mathrm{H}, \mathrm{O})$ & Mass $\%$ & $86,14,0$ & $52,13,35$ & $0,100,0$ \\
\hline Molecular weight & $\mathrm{Kg} \mathrm{ml}$ & 114.15 & 46.07 & 2.02 \\
\hline Density at $15{ }^{\circ} \mathrm{C}$ & $\mathrm{Kg} / \mathrm{m}^{3}$ & 737 & 793.2 & 0.0838 \\
\hline $\mathrm{LHV}$ & $\mathrm{MJ} / \mathrm{kg}$ & 43.5 & 26.3 & $\mathrm{HIV}$ \\
\hline $\mathrm{HHV}$ & $\mathrm{MJ} / \mathrm{kg}$ & 47.3 & 29.1 & 142.2 \\
\hline Viscosity at $20{ }^{\circ} \mathrm{C}$ & $\mathrm{mm}-\mathrm{s}-1$ & 0.37 to 0.44 & 1.3 & - \\
\hline Stoichiometric air-fuel ratio & $\mathrm{W} / \mathrm{W}$ & $14.2-15.1$ & 8.97 & 34.3 \\
\hline Research octane number & - & $91-100$ & $108.61-110$ & 130 \\
\hline Autoignition temperature & ${ }^{\circ} \mathrm{C}$ & 257 & 425 & 584.85 \\
\hline Vapor flammability limits & $\mathrm{vol} \%$ & $0.6-8$ & $3.5-15$ & $4-75$ \\
\hline
\end{tabular}

Previous research has been carried out on the SI engine by using $10 \%$ anhydrous ethanol and hydrous ethanol (5\% water volume fraction) mixed with $90 \%$ gasoline, causing decreases the cylinder pressure compared to gasoline fuel. The higher peak pressure is produced by using hydrous ethanol at the engine load of 100 N.m, compared to both fuels, anhydrous ethanol and gasoline [18]. Higher ethanol concentrations up to $20 \%$ by volume in the gasoline fuel resulted in the engine performance decreasing. In contrast, exhaust gas emissions such as hydrocarbon $(\mathrm{HC})$, carbon monoxide $(\mathrm{CO})$, and carbon dioxide $\left(\mathrm{CO}_{2}\right)$ are significantly reduced [19]. The experiment of pure ethanol on the SI engine showed significantly reducing cylinder pressure compared to gasoline and 10\% ethanol mixture fuel [20]. According to research conducted by Mohammed et al., resulting in an increase in the engine power and efficiency with increase the ethanol fraction up to $40 \%$ and decrease brake specific fuel consumption (BSFC) by about $17.21 \%$, and the emissions of $\mathrm{CO}, \mathrm{CO}_{2}, \mathrm{HC}$, and nitric oxide $\left(\mathrm{NO}_{x}\right)$ produces decrease significantly, and higher ethanol content effected to decreased volumetric efficiency [21]. In other studies, increasing the ethanol fraction reduces $\mathrm{HC}$ and $\mathrm{CO}$, whereas increasing $\mathrm{NOx}$ emissions due to the ethanol fuel containing $\mathrm{O}_{2}$ caused a higher flame speed during the combustion process[15]. The combustion process in the SI engine very quickly cause produces high peak pressure and affects the increase in the cylinder temperature [22].

\section{Method}

An experimental setup was designed for evaluating the effect of hydrogen enrichment of the four-stroke engine-fueled gasoline-bioethanol blends. The full-grade bioethanol $(99,8 \%)$ is used to blend into gasoline fuel. The bioethanol was mixed with gasoline fuel of $10 \%$ by volume. The engine operated with different speeds between about 2000 and $11000 \mathrm{pm}$. The hydrogen is produced from the water electrolysis process of a dry cell electrolyzer. Dry Cell Electrolyzer consists of an array of 316L stainless steel plates with a total of 16 cells., which is equipped with a membrane as a separator of oxygen and hydrogen. The fraction of Sodium Hydroxide (NaOH) was $5 \%$ by weight was mixed with distillate water as the electrolyte has used. The electrolyzer is equipped with pulse width modulation (PWM) to control hydrogen produce, by controlling the voltage and current supplied to the electrolyzer. In addition, other devices such as flow, thermocouple, voltage, and ampere sensors are connected to a microcontroller (MyRio) with a LabVIEW interface. The test was carried out using gasoline fuel, gasoline-bioethanol blend, and fuels blend with hydrogen enrichment, supplied through the intake manifold with two separate injectors. The signal of all sensors connected directly to the engine is recorded in real-time during engine operation.

\subsection{Electrolyzer}

The electrolysis of water produces HHO gas, which has been utilized as a fuel mixture in SI engines. This research designed and manufactured a dry cell electrolyzer using 316L stainless steel. A monofilament screen separator has separated every cell that produces HHO to separate pure hydrogen and oxygen. A fraction of sodium hydroxide $(\mathrm{NaOH})$ of $5 \%$ by weight was blended with distillate water as the electrolyte. Pulse Width Modulation (PWM) was used to control HHO production. Hydrogen is supplied through to the throttle body using an injector at a constant pressure of $10 \mathrm{psi}$, held using a bypass regulator. The timing of the hydrogen injection is the same as the time of the gasoline injector. 


\subsection{Engine testbed}

The experimental setup, the schematic view of the engine setup is shown in Fig. 1, consists of a test engine, dynamometer, Gas analyzer, thermocouple, and pressure transducer. The four-stroke engine with variable valve actuation (VVA), four-valve, and Liquid-cooled include the engine control unit (ECU) to control fuel injection, advance spark timing, and activate VVA at the engine speed of $7400 \mathrm{rpm}$.

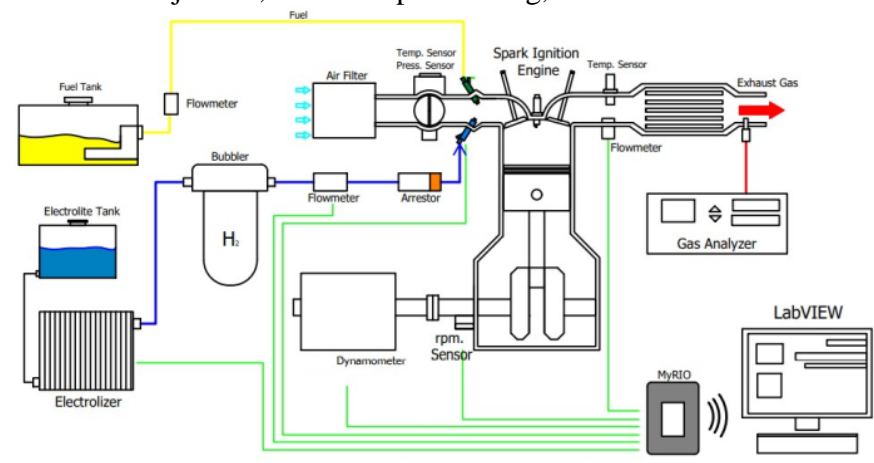

Fig 1. Schematic view of the engine setup

The sensors installed on the engine are connected to a microcontroller (NI-MyRIO) and communicate with interface Laboratory Virtual Instrument Engineering Workbench (LabVIEW 2015). The signals of all sensors can be recorded in real-time according to the intervals applied. The Gas analyzer was used E-Instrument E-8500 to measure the $\mathrm{CO}, \mathrm{CO}_{2}, \mathrm{NO}, \mathrm{NO}_{2}$, and $\mathrm{CxHy}$, emissions.

\section{Results and Discussion}

This section explains the experimental results of the emissions analysis of the SI engine fueled by gasoline-bioethanol blending and hydrogen enrichment. The SI engine emitted hydrocarbons $(\mathrm{CxHy})$, carbon dioxide $\left(\mathrm{CO}_{2}\right)$, carbon monoxide $(\mathrm{CO})$, and nitrogen oxides $(\mathrm{NO} x)$ at different engine speeds ranging from 2000 to $11000 \mathrm{pm}$.

\subsection{Hydrocarbon's emissions $(\mathrm{CxHy})$}

Using a 10\% gasoline-bioethanol (BE10) increased CxHy emissions with the most significant value of $1.501 \%$ CxHy was at $1658 \mathrm{rpm}$ engine speed, compared to $0.349 \% \mathrm{CxHy}$ emissions from pure gasoline. The effect of hydrogen enrichment of BE10 reduced the production of CxHy emissions. The CxHy emission on the BE10+H2 is $0.91 \%$ at 1723 RPM engine speed, or $0.591 \%$ less than the use of BE10.

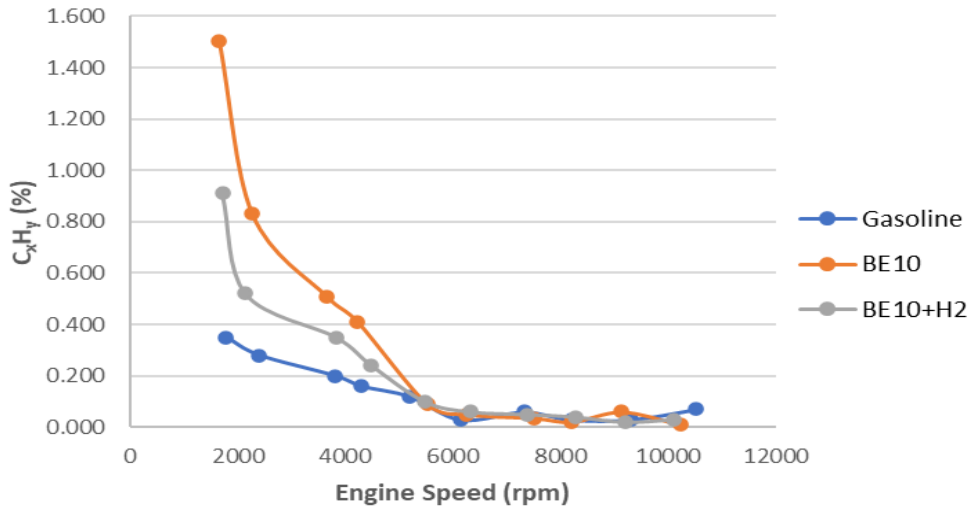

Fig 2. The HC emission results of the fuels mixture at various engine speed

Figure 2 shows hydrocarbon emissions resulting from the combustion of pure gasoline, BE10, and BE10+ $\mathrm{H}_{2}$. The result indicates that hydrocarbon emission products regarding fuel mixture decreased significantly up to engine speed at $6000 \mathrm{pm}$. The stoichiometry reaction of the fuel mixture was achieved at a rate above $6000 \mathrm{rpm}$. Hydrocarbon emissions are generated during the re-action without oxygen in the fuel-air combination and the inhomogeneous of the fuel-air variety. The effect of oxygen in bioethanol increased the homogeneity and boosted the flame speed of the combustion reaction, conducted stability, and reduced hydrocarbon emissions. The addition of ethanol to the fuel mixture decreased the temperature of the combustion chamber [23]. When the engine is running at a higher speed, the cylinder's temperature rises, increasing the conversion rate and reducing the hydrocarbon emissions compared to the lower engine speed.

\subsection{Carbon dioxide $\left(\mathrm{CO}_{2}\right)$}

The usage of $\mathrm{BE} 10$ fuel increased $\mathrm{CO}_{2}$ emissions while the highest value at $8207 \mathrm{rpm}$ with $14.74 \% \mathrm{CO}_{2}$ emission, compared to the pure gasoline was $14.19 \% \mathrm{CO}_{2}$ emissions, it's increased $0.6 \%$ of $\mathrm{CO}_{2}$ in $\mathrm{BE} 10$ compared to pure gasoline. The effect of hydrogen enrichment of $\mathrm{BE} 10\left(\mathrm{BE} 10+\mathrm{H}_{2}\right)$ tendency to reduce $\mathrm{CO}_{2}$ emissions about $0.8 \% \mathrm{CO}_{2}$ at $8276 \mathrm{rpm}$ engine speed compared to the BE10. The highest value of the $\mathrm{CO}_{2}$ emission regarding $\mathrm{BE} 10+\mathrm{H}_{2}$ is $13.94 \%$ at a rate of bout $9000 \mathrm{rpm}$. Additional hydrogen to fuel-air mixture affected the stability of combustion reaction. 


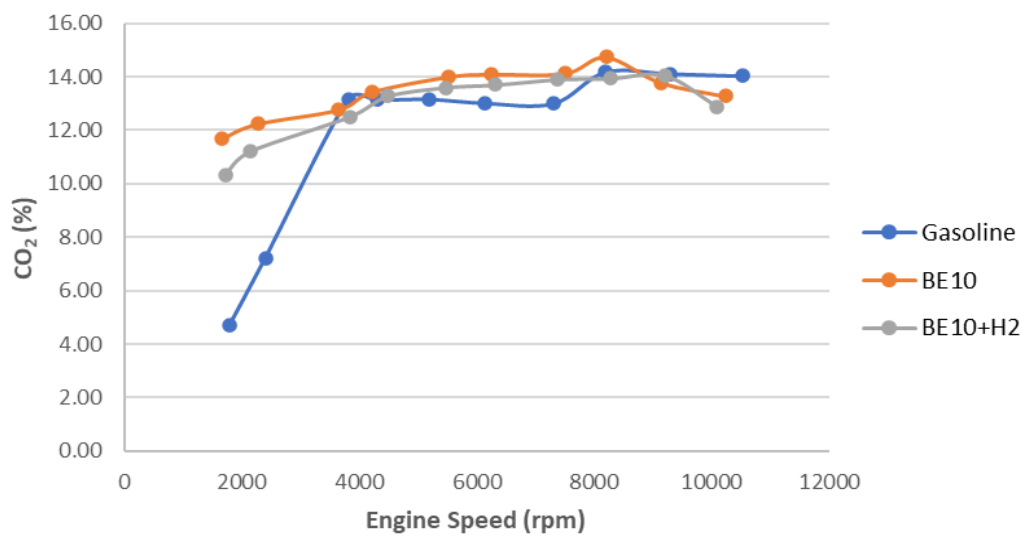

Fig 3. The $\mathrm{CO}_{2}$ emission results of the fuels mixture at various engine speed

Figure 3 shows the $\mathrm{CO}_{2}$ emissions produced during testing with hydrogen enrichment in pure gasoline, $\mathrm{BE} 10$, and $\mathrm{BE} 10+\mathrm{H}_{2} . \mathrm{CO}_{2} \mathrm{emissions}$ are the primary product of hydrocarbon fuel. The result shows carbon dioxide emission product regarding fuel mixture increasing slowly coinciding with engine speed. $\mathrm{CO}_{2}$ emissions increased compared to pure gasoline due to an increasing combustion process near stoichiometry with oxygen content in ethanol fuel [24]. The hydrogen enrichment produced $\mathrm{CO}_{2}$ emission due to the unavailability of carbon content in hydrogen fuel. As a result, the $\mathrm{C} / \mathrm{H}$ ratio is lower than for mixed fuels.

\subsection{Carbon Monoxide (CO)}

Carbon monoxide emissions are produced by incomplete combustion due to a lack of oxygen during the reaction. Figure 4 shows the usage of $\mathrm{BE} 10$ and $\mathrm{BE} 10+\mathrm{H}_{2}$ increased $\mathrm{CO}$ emissions in low rpm engine speed. The highest value was $6796 \mathrm{ppm} \mathrm{CO}$ at $1658 \mathrm{rpm}$. Compared to pure gasoline was $4750 \mathrm{ppm} \mathrm{CO}$ emissions at $1793 \mathrm{pm}$.

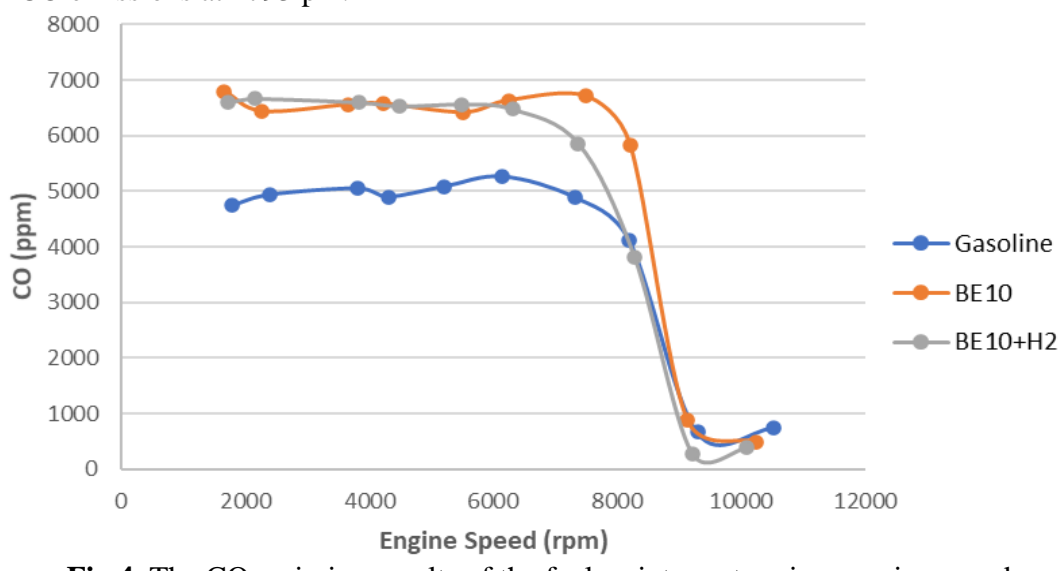

Fig 4. The $\mathrm{CO}$ emission results of the fuels mixture at various engine speed

The effect of hydrogen enrichment in BE10 affected the decrease in $\mathrm{CO}$ emission, and the combustion process was more stable than pure gasoline and BE10. At low engine speed in the range of $1658 \mathrm{rpm}$ to $7503 \mathrm{rpm}$, CO emissions resulted higher than high engine speed at above $7500 \mathrm{rpm}$. This phenomenon is due to the engine's active VVA, which increased the turbulence of the fuel-air mixture through the intake valve to the cylinder, thus increasing the homogeneity of the fuel-air mixture. The hydrogen enrichment affected the lower $\mathrm{CO}$ emission than pure gasoline and BE10.

\subsection{Nitrogen oxides (NOx)}

The usage of BE10 increased the $\mathrm{NO}_{x}$ emissions with the high rpm of engine speed. The highest value was $102.15 \mathrm{ppm} \mathrm{NO}$ at $8207 \mathrm{rpm}$ engine speed compared to the pure gasoline was $92.35 \mathrm{ppm} \mathrm{NO}_{x}$ emissions at $8197 \mathrm{rpm}$ engine speed. On the other hand, hydrogen enrichment of BE10 influenced decreased $\mathrm{NO}_{x}$ emissions. The $\mathrm{NO}_{x}$ emission value was $73 \mathrm{ppm}$ at $8276 \mathrm{rpm}$ engine speed. 


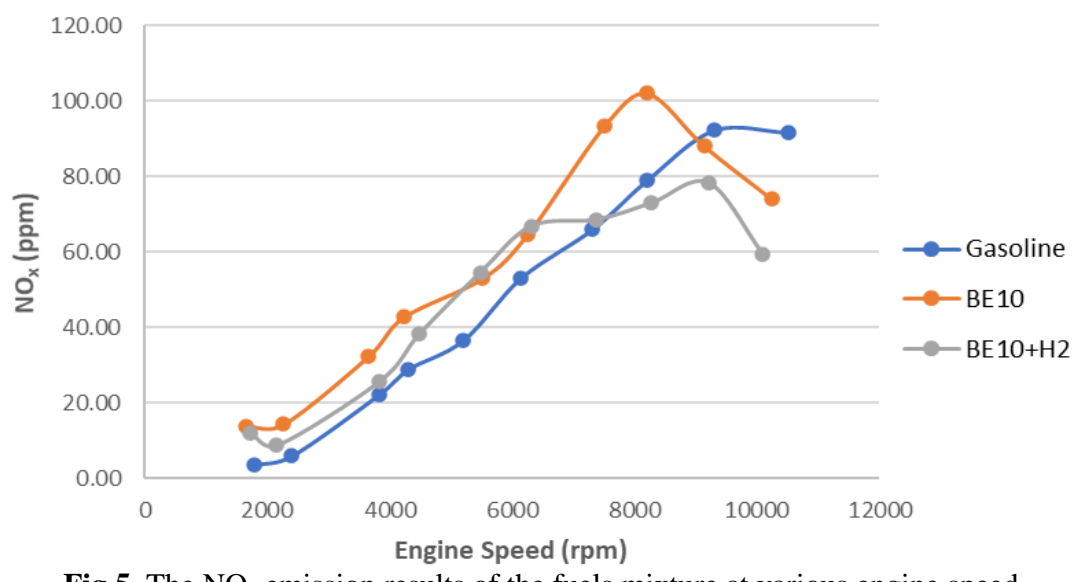

Fig 5. The $\mathrm{NO}_{x}$ emission results of the fuels mixture at various engine speed

Figure 5 shows $\mathrm{NO}_{x}$ emission increased relatively to the engine speed. At the same engine speed, $\mathrm{NO}_{x}$ emission produced higher when operated with hydrogen enrichment. Due to the high flame speed of hydrogen, this phenomenon affected to increase the temperature reaction during the combustion process. Hydrogen enrichment improved thermal energy conversion efficiency, and the high flame speed of hydrogen generated the stability of the combustion reaction. The disadvantage of the bioethanol and hydrogen enrichment increased the $\mathrm{NO}_{x}$ emission. However, $\mathrm{NO}_{x}$ emissions could be controlled and reduced by using a catalytic converter in the exhaust system. In another study, the production of $\mathrm{NO}_{x}$ increased while the load was conducted on the engine due to the increase of reaction temperature in the combustion chamber [25].

\section{Conclusion}

The emission characteristics of the single-cylinder SI engine fueled gasoline-bioethanol blended with hydrogen enrichment were studied. The Ethanol-gasoline- $\mathrm{H}_{2}\left(\mathrm{BE} 10+\mathrm{H}_{2}\right)$ was an excellent candidate as a new alternative fuel solution regarding emission products. The enrichment of hydrogen increased the flame speed during the combustion reaction. The duration of the combustion reaction also shortens generated. However, the production of $\mathrm{NO}_{x}$ increased influenced by the higher temperature of the combustion reaction. The hydrogen enrichment produced $\mathrm{CO}_{2}$ emission due to the unavailability of carbon content in hydrogen fuel. As a result, the $\mathrm{C} / \mathrm{H}$ ratio is lower than for mixed fuels.

\section{Acknowledgement}

Gratefully acknowledges financial support from the Institute for Research and Community Service (LPPM) Universitas Malikussaleh, Aceh, Indonesia.

\section{References}

[1] A. A. Yusuf and F. L. Inambao, "Progress in alcohol-gasoline blends and their effects on the performance and emissions in SI engines under different operating conditions," International Journal of Ambient Energy, vol. 42, pp. 465-481, 2021/03/12 2021.

[2] A. H. Sebayang, H. H. Masjuki, H. C. Ong, S. Dharma, A. S. Silitonga, T. M. I. Mahlia, et al., "A perspective on bioethanol production from biomass as alternative fuel for the spark-ignition engine," RSC Advances, vol. 6, pp. 1496414992, 2016.

[3] C. Bae and J. Kim, "Alternative fuels for internal combustion engines," Proceedings of the Combustion Institute, vol. 36, pp. 3389-3413, 2017/01/01/ 2017.

[4] DEN, Outlook Energi Indonesia (OEI) 2019. Jakarta: Dewan Energi Nasional (DEN), 2019.

[5] D. Y. Dhande, N. Sinaga, and K. B. Dahe, "Study on combustion, performance and exhaust emissions of a bioethanolgasoline blended spark-ignition engine," Heliyon, vol. 7, p. e06380, 2021/03/01/ 2021.

[6] A. A. Yusuf and F. L. Inambao, "Effect of low bioethanol fraction on emissions, performance, and combustion behavior in a modernized electronic fuel injection engine," Biomass Conversion and Biorefinery, vol. 11, pp. 885-893, 2021/06/01 2021.

[7] M. İ. İlhak, R. Doğan, S. O. Akansu, and N. Kahraman, "Experimental study on an SI engine fueled by gasoline, ethanol, and acetylene at partial loads," Fuel, vol. 261, p. 116148, 2020/02/01/ 2020.

[8] B. Shadidi, G. Najafi, and T. Yusaf, "A Review of Hydrogen as a Fuel in Internal Combustion Engines," Energies, vol. 14, p. 6209, 2021.

[9] L. Brennan and P. Owen, "Biofuels from microalgae-A review of technologies for production, processing, and extractions of biofuels and co-products," Renewable and Sustainable Energy Reviews, vol. 14, pp. 557-577, 2010/02/01/ 2010.

[10] A. Bušić, N. Marđetko, S. Kundas, G. Morzak, H. Belskaya, M. Ivančić Šantek, et al., "Bioethanol Production from Renewable Raw Materials and Its Separation and Purification: A Review," Food technology and biotechnology, vol. 56, pp. 289-311, 2018.

[11] M. B. Celik, "Experimental determination of suitable ethanol-gasoline blend rate at high compression ratio for gasoline engine," Applied Thermal Engineering, vol. 28, pp. 396-404, 2008/04/01/ 2008. 
[12] S. Yousufuddin, S. N. Mehdi, and M. Masood, "Performance and Combustion Characteristics of a Hydrogen-EthanolFuelled Engine," Energy \& Fuels, vol. 22, pp. 3355-3362, 2008/09/17 2008.

[13] M. A. S. Al-Baghdadi, "Hydrogen-ethanol blending as an alternative fuel of spark-ignition engines," Renewable Energy, vol. 28, pp. 1471-1478, 2003/07/01/ 2003.

[14] C. R. Ferguson and A. Kirkpatrick. (2016). Internal combustion engines: applied thermosciences (Third edition. ed.) [text].

[15] H. Köten, Y. Karagöz, and Ö. Balcı, "Effect of different levels of ethanol addition on performance, emission, and combustion characteristics of a gasoline engine," Advances in Mechanical Engineering, vol. 12, p. 1687814020943356, 2020/08/01 2020 .

[16] T. Le Anh, K. Nguyen Duc, H. Tran Thi Thu, and T. Cao Van, "Improving Performance and Reducing Pollution Emissions of a Carburetor Gasoline Engine by Adding HHO Gas into the Intake Manifold," 2013.

[17] A. C. Yilmaz, E. Uludamar, and K. Aydin, "Effect of hydroxy (HHO) gas addition on performance and exhaust emissions in compression ignition engines," International Journal of Hydrogen Energy, vol. 35, pp. 11366-11372, 2010/10/01/ 2010.

[18] X. Wang, Z. Chen, J. Ni, S. Liu, and H. Zhou, "The effects of hydrous ethanol-gasoline on combustion and emission characteristics of a port injection gasoline engine," Case Studies in Thermal Engineering, vol. 6, pp. 147-154, 2015/09/01/ 2015.

[19] S. O. Akansu, S. Tangöz, N. Kahraman, M. İ. İlhak, and S. Açıkgöz, "Experimental study of gasoline-ethanol-hydrogen blends combustion in an SI engine," International Journal of Hydrogen Energy, vol. 42, pp. 25781-25790, 2017/10/05/ 2017.

[20] B. Sayin Kul and M. Ciniviz, "Assessment of waste bread bioethanol-gasoline blends in respect to combustion analysis, engine performance and exhaust emissions of a SI engine," Fuel, vol. 277, p. 118237, 2020/10/01/ 2020.

[21] M. K. Mohammed, H. H. Balla, Z. M. H. Al-Dulaimi, Z. S. Kareem, and M. S. Al-Zuhairy, "Effect of ethanol-gasoline blends on SI engine performance and emissions," Case Studies in Thermal Engineering, vol. 25, p. 100891, 2021/06/01/ 2021.

[22] G. L. Borman and K. W. Ragland, Combustion Engineering. United States of America: McGraw-Hill, 1998.

[23] B. Doğan, D. Erol, H. Yaman, and E. Kodanli, "The effect of ethanol-gasoline blends on performance and exhaust emissions of a spark-ignition engine through exergy analysis," Applied Thermal Engineering, vol. 120, pp. 433-443, 2017.

[24] V. Saikrishnan, A. Karthikeyan, and J. Jayaprabakar, "Analysis of ethanol blends on spark ignition engines," International Journal of Ambient Energy, vol. 39, pp. 103-107, 2018/02/17 2018.

[25] N. D. S. A. Santos, C. E. C. Alvarez, V. R. Roso, J. G. C. Baeta, and R. M. Valle, "Combustion analysis of a SI engine with stratified and homogeneous pre-chamber ignition system using ethanol and hydrogen," Applied Thermal Engineering, vol. 160, p. 113985, 2019/09/01/ 2019. 